\title{
Film as an Agent of Human Rights Advancement in Nigeria: A Study of Bloody Night and Somewhere in Africa
}

\author{
Emmanuel Onyeka Ebekue \\ \& Somtoo Arinze-Umobi
}

http://dx.doi.org//10.4314/ujah.v17i2.4

\section{Abstract}

Human rights are those inalienable rights that are basically accruable to every human person or citizen of a country. In Nigeria, the human rights situation is worrisome to say the least, as the nation goes on pursuing her phantom democratisation objectives. Against the background of a vibrant and popular film culture in Nigeria, this study has investigated the role of film in the advancement of human rights ideals. Using two films produced in Nigeria's vibrant film industry Nollywood,- Charles Offor's Bloody Night and Kwame Boadu \& Frank Rajah Arase's Somewhere in Africa; the study paradigmatically interrogates issues of human rights portrayed in the films. The study is qualitative in approach, combining both textual analysis and focus group discussion (FGD). The films under study were subjected to textual analysis while two FGD sessions were conducted among randomly selected students of Nnamdi Azikiwe University, Awka, Nigeria - six discussants for each session. The data from the textual analysis and FGSD were separately analysed. Findings show that the two films are able to project the systemic inadequacies of human rights culture in Nigeria and offer an ideological alternative, and that the audience understood the film's message in the context of the quest for human rights in Nigeria and were able to relate the situations portrayed in the films to their own real life situations as Nigerians. 
Key words: Film, human rights, human rights culture, human rights situation

\section{Introduction}

Human rights and respect thereof have been a key issue of Nigeria's nationhood experience. This is particularly true in the light of the nation's poor democratic credentials as evidenced in the fact that military rule accounts for roughly 27 years $(50 \%)$ of the 54 years of the nation's experience as an independent nation democracy. Many years of successive military regimes have left Nigeria with an underdeveloped human rights culture. However, there is little doubt that Nigeria as a nation, at least in principle, has recognised the prime place of human rights in her national life. Little wonder, human rights provision has been a key part of the nation's successive constitutions as observed by Chukwumerije (2014):

All the four constitutions written since 1960 1963, 1978, 1989 and 1999 - and all the laws in the statute books relevant to rule of law and human rights show remarkable consistency in respecting the principle of preserving human dignity through good governance. The framework for upholding human dignity such as division of powers among three realms of governance (Executive, Legislative and Judiciary) and rights and obligations of citizens - has been left intact by each constitution.

Nonetheless, the matter of concern in Nigeria is how far these human rights-friendly laws have translated to sustainable respect for humans rights in real time among Nigerians. While remarkable improvement in has been acknowledged with return of democracy in Nigeria 15 years ago, the popular sentiment is that Nigeria is yet to evolve an 
efficient and sustainable human rights culture that would place her at par, or at least nearly at par, with some "model" democracies of the world. The Human Rights Watch, in her 2013 report, found wide spread of human rights abuses in Nigeria notably in the areas of right to life, free speech, fair trial, etc (Human Rights Watch, 2014). With reference to abuses by the nation's police force, the body notes:

Nigeria's police force continues to be implicated in frequent human rights violations, including extrajudicial killings, torture, arbitrary arrests, and extortion-related abuses. Despite promising public statements by the new inspector general of police, corruption in the police force remains a serious problem. The police routinely solicit bribes from victims to investigate crimes and from suspects to drop investigations. Senior police officials embezzle or mismanage police funds, often demanding monetary "returns" from money that their subordinates extort from the public.

Human rights abuses in Nigeria have over the years attracted the response of individual and group activists who have pushed for improved human rights culture in the country. According to Chukwumerije (2014), "The progressive deterioration of the status of human rights in the seventies and eighties combine with the inspiration of foreign events and foreign aids to stimulate the stirrings of the civil society and accelerate the growth of civil society and human rights bodies. Today, there are over fifty such bodies, led by Civil Liberties Organization, Human Right Defence Group, and Women in Nigeria." Nevertheless, these groups, individuals and other stakeholders advocating for an improved human rights culture in Nigeria would inevitably require the media to get their 
message across to the vast population of the country. This is where communication comes in as a key agent for human rights advancement. According to the Centre for Community Journalism and Development (2014), "The media play an enormously important role in the protection of human rights. They expose human rights violations and serve as medium for different voices to be heard."

Among the various media forms in Nigeria, locally produced films easily stand out as one of the most influential. Fondly referred to as Nollywood, the film industry in Nigeria, which received impetus in 1992 with the release of the blockbuster Living in Bondage as produced by Kenneth Nnebue, has quickly and continuously gathered momentum over the last two decades emerging today as a force to reckon with globally (Haynes \& Okome, 1998; Ozoemena, 2006; Chauncey, 2012). The industry has in the last two decades been enjoying a massive local viewership. In the words of Ozoemena (2006), "Nigeria has a keen, if relatively new, obsession with home-grown movies - almost exclusively shot on digital and available only on video." Thus without doubts, locally produced films have come to occupy an important place in the realm of Nigeria's contemporary communication culture which arguably positions them as a veritable tool for ideological propagation and social change. They have become a platform for projection of communal experience, values and norms. All this makes the local film industry a potentially powerful tool for promotion of human rights through projection of themes that reflect the negative human rights experiences of Nigerians and offering ideological alternatives. Stated differently, given their popularity among the populace, locally produced films have the potential to shape the discourses on the rights of the girl child.

It is against this background that this study investigated the role of films as an agent of human rights 
advancement in Nigeria. It did this with particular reference to the two films, Bloody Night and Somewhere in Africa.

\section{Objectives of the study}

The purpose of this research was to investigate the role which film could play in the quest to advance human rights culture in Nigeria. Specifically, the following objectives were targeted:

i. To find out the extent the films Bloody Night and Somewhere in Africa mirror the systemic inadequacies in human rights realisation in Nigeria;

ii. To discover the implicit and/or explicit ideological thrust of the two films in the context of human rights discourses in Nigeria;

iii. To find out how the audience understand and interpret the message of the films in the context of human rights realisation in Nigeria.

\section{Research questions}

Following the above objectives, the following research questions were posed:

1. To what extent do the films Bloody Night and Somewhere in Africa mirror the systemic inadequacies in human rights realisation in Nigeria?

2. What are the implicit and/or explicit ideological thrust of the two films in the context of human rights discourses in Nigeria?

3. How does the audience understand and interpret the message of the films in the context of human rights realisation in Nigeria? 


\section{Methodology}

The study is qualitative in approach combining both textual analysis and focus group discussion (FGD). The two films under study were subjected to textual analysis while two FGD sessions were conducted among students of Nnamdi Azikiwe University, Awka, Nigeria - six discussants for each sessions. The data from the textual analysis and FGSD were separately analysed and then employed in answering the research questions.

\section{Synopsis of the Films Under Study}

\section{Bloody Night}

Bloody Night, a 2014 film produced by Charles Offor and directed by Emma Aniekwe orchestrates the illegal and obnoxious activities of the Special Anti Robbery Squad (SARS), a department of the Nigerian Police Force, in the eastern part of Nigeria. Fimba, Nwanneka and Kelvin are arrested on their way back from a night club at late hours by the SARS based on a distress call from Doctor Okon. The doctor comes to the police station and vindicates the suspects, as a result Fimba is rushed to the hospital by men of the SARS. The doctor announces him dead. In a bid to cover up their action, the suspects are labeled armed robbers while Dr. Okon corroborates the story in a statement as a result of a blackmail threat from the leader of the SARS. Owing to her father's influence, Nwanneka is released on bail. She fights against the SARS in a bid to obtain justice for dead Fimba who is also her fiancé. Finally, Dr. Okon confronts his fears and confesses to the truth. The SARS team is prosecuted and capital punishment is pronounced on them in accordance with the law while Nwanneka obtains her long sought justice as Fimba and Kelviln are cleared of the robbery allegation against them. 


\section{Somewhere in Africa}

Produced by the duo of Kwame Boadu and Frank Rajah Arase (and directed by the latter), the film is a metaphorical representation of the nature of leadership in Africa and the horrors perpetrated by most African leaders in a quest to acquire and retain power. Released in 2012, Somewhere in Africa tells the story of General Mumbasa who topples the democratic government and announces himself president. He suspends the constitution and kills all the serving ministers and other government functionaries with their families. Mrs. Archiblong, a secondary school teacher whose husband was also killed during General Mumbasa's purge starts to lead the civil rights movement to counter Mumbasa's ruthless leadership. She is captured and shot in front of her only daughter and some other school kids. The daughter leads a protest march to Mumbasa's residence, he orders the shooting of the protesting school kids. The rest are caught and remanded in his prison where they are brutalized with the girls among them raped. The remaining daughter of the Archibong's and some of her friends are brutally amputated and maimed. Finally, Mumbasa is toppled and all the political prisoners are freed.

\section{Textual Analysis of the Films in the Context of Nigeria's Human Rights Situation}

One of the major problems facing adequate institutionalization and actualization of the human rights in Nigeria is corruption and lack of respect for the sanctity of human person. Corruption has eaten deep into the fabrics of the Nigerian system and has virtually made justice and equity impossible within the Nigerian setup (Human Rights Watch, 2010; Edukugho, 2013). This cankerworm has eaten deep into the fabrics of the Nigerian police system. This is actually the crux of the matter in Bloody Night. The Special Anti-Robbery 
Squad (SARS) is alerted of a robbery that just took place, they see a group of young men coming back from a night club and label them the 'robbers'. Instead of taking them into custody for investigation, they decide to shoot at one of them even though they found no arms on him. On finding out that they have the wrong people, instead of finding ways to make amends, they decide to cover up their mistake by framing the group as the said robbers. From the masterly manner they orchestrate this, one will see that these cover-ups and frameups of innocent individuals have become habitual in the line of their duty. "Oga, we can call it a case of stray bullets, we were in pursuit of armed robbers and the bullet hit him." This is one of the suggestions put up by one of the policemen to their commander as they look for a way to cover up their mess. Cases of "stray bullets" have become very frequent with the Nigerian security forces. It has become the cliché for covering up cases of extra judicial killings orchestrated by the police. They go out in the streets and arrest innocent people just to extort bail money from them even when bail is supposed to be free in Nigeria. Many of the suspects are detained for very long in the cells without being charged to the courts. Many have different parts of their bodies maimed as a result of torture from the police. All these are breach of human rights made evident in the film. Kelvin is shot on the leg so as to coerce him into signing a statement written by the police indicting him and his friends in the accusation leveled against them.

The whole system smells of filth starting with the force that are supposed to protect the citizen to the citizens who should protect each other but rather is coerced into bearing false witnesses against each other in a bid to cover up their sordid past. "Let me tell you, when stupid charge and bail lawyers like you sneeze, powerful officers like me won't catch cold ... because those boys and girls in the office of the 
commissioner of police, I pay their bills." This outburst from the SARS leader to the human rights lawyer that is investigating into the case tells one of the kind of corruption that has enveloped the whole system. A petition that's written to the commissioner is intercepted by his office aids and sent to the person whom the petition is against just because the aids are in the "the payroll" of the corrupt SARS commandant. It is one whole big system that must be sanctified for human rights to make meaning and gain a sizeable ground in Nigeria.

Somewhere in Africa also pitches the bane of human rights in Nigeria; the lack of respect for dignity of the human person. Many of the leaders get into power not because they have the yearning to affect the lives of the citizens positively but because of their lust and inordinate desire for power. As a result, they do everything possible to take power not minding who gets hurt or who is violated. General Mumbasa is a typical example. He masterminds a coup and topples the democratic government, kills all the government functionaries and their families and tracks anyone who dares blink an eye. He proclaims himself a god and institutes a reign of carnage. This in effect mirrors the psychological makeup of many of Nigerian leaders. Many of them celebrate the culture of impunity, believing themselves to be above the whole citizenry who vote them into power. They are allergic to opposition and criticism and so go to any length to stifle the "stray voices". It is this disregard endemic in the leadership system that makes General Mumbasa to order the shooting of secondary school students protesting the unlawful abduction of their teacher from their classroom. This could be likened to the Ogoni massacre in 1999 when president Obasanjo ordered an attack on the village in retaliation for soldiers killed by hoodlums in the area. The Ijaw National Congress Report on Ogoni massacre describes it thus; 
Five days clear of the 24 November ultimatum, the President lost his patience and invoked emergency powers. Forty-eight hours later, the rural town of Odi was leveled. Only a church and a bank building survived the operation. Nothing which had life -- man or animal -- was moving. They were either dead or in hiding in the bushes. Over 300 were reported killed ...( (Osita, 1999).

However the films have hope and revivification as their ideological thrust. They try to raise hope in the future and the enculturation of the humanist values at the core of our systems. They are apparently intended to motivate people not to give up hope but to fight on because that's only the desired change can come. Thus, in the film Bloody Night, Rev. Frank motivates the students;

They need to hear your cry, they need to hear you scream; why are you killing us? Let them hear, be your own army. Let them hear what you want. Let them hear what you do not want. If you do not we will all perish.

It is also this persistent push in the face of despair and hopelessness that leads to the turnaround of events in Bloody Night. Gift having exhausted all the legal options available to her, meets with no progress as the system is gagged from within. She does not give up hope but continues to frequent the house of Dr. Okon who has connived with the police. With the constant visits, Dr. Okon's hardened mind snaps, he goes to the police and confesses the truth. Gift and her friends get justice and the body of poor Fimba is released to the family for burial.

\section{Analysis of Focus Group Discussion Data}

Two FGD sessions were conducted. Each session had six discussants drawn from the undergraduate students of 
Nnamdi Azikiwe University, Awka, Nigeria. Four of the discussants are male $(33.3 \%)$ while eight are female $(62.7 \%)$. Their ages ranged between 19 and 24 years and which amounted to the average age of 21.2 years. The respondents were in no doubt as they asserted that the two films under study aptly projected the human rights worries of Nigeria. It was apparently not difficult for most of them to see in the two films a reflection of the human rights shortcomings of the country where they have grown and lived.

In Bloody Night, the respondents could see a depiction of the skewed justice situation not uncommon in their country - where the security agencies (particularly the police) become instrument of arbitrary arrest, detention and extrajudicial killing and where justice has become difficult for the poor to access. One of the discussants Osakwe said this about the film:

The film projected that human rights is something difficult and hard to pursue in Nigeria. It creates a picture where the poor can hardly get justice and even the rich who try get it go the extra mile to succeed.

Another discussant Cynthia believed that the film should be viewed by every Nigerian given its relevance to the human rights question in the country. She added:

The film reveals to us the difficulty faced by human rights organisations in pursuing people's rights. These organisations do not even have the free hand to solicit for their clients whose rights have been trampled upon by the rich in the society who employ their wealth to cover up their crimes

Generally, the audience had no difficulty relating the role of the Special Anti-Robbery Squad (SARS) in the film to 
the role they have been believed to play in real life. This department of the Nigerian Police Force has over the years been notoriously alleged to have arrested, tortured and murdered people on allegations of one crime or the other without following the due process of the law (Falayi, 2014). The respondents saw in Bloody Night a reflection of such abuse of power and mindless disregard for the people's rights.

Then in Somewhere in Africa, the discussants saw a reflection of the evils of military interventions and wars; a key threat to human rights in Africa and Nigeria. A respondent Frank related the film to the ugly political experiences of Nigeria beginning from 1966 when coups, counter-coups and a civil war had left human rights under siege:

We can see in the film a depiction of what took place in Nigeria starting from the 1966 coup d'état. What happened in the film reflects the case of Nigeria where a long period of repressive military rules eventually gave way for a more liberal democracy.

Similarly, another respondent Oluchukwu had this to say:

The film depicts out government and the poor masses; how the government intoxicated with power treats the people badly denying them freedom of speech and forcing them to live under its (government's) repressive control.

Apparently, the respondents could identify with the setting of the film as reflecting their nation's political history. The film was set in the 1960s when Nigerian experienced two military coups and a civil war - the Biafran war. This fact seemed to have contributed in driving home the message of the film. However, one of the discussants Gift noted that "though the film centres on the Biafran war, it projects the challenges of rights and freedom confronting Nigerians even 
today."Hence, Franklin could relate the film to the deadly insurgencies of the Islamist fundamentalist group Boko Haram and to the general insecurity in the land, which all threatens the rights of the citizenry. Said he:

Actually the film projects the abuse of human rights in Nigeria which I can relate to the current insurgent activities of Boko Haram and the insecurity in the country. The government laid the foundation for all this anomaly, discrimination, poverty, lack of access to basic amenities and ethnic tension which all negatively affect the growth of nation.

Expectedly, the respondents immediately saw in the two films some relevant lessons for Nigeria as she pursues her objective of democratisation and human rights realisation. In regard to Bloody Night, Cynthia thought as follows:

This film is a means of telling the authorities who might not know about the happenings within our security agencies and how to improve on their services to the people. Nigerians are also to learn from the film how to protect their rights and stand firm in getting justice for themselves irrespective of the difficulties and how long it may take.

For Osakwe:

One major lesson here is that one has to fight for justice even if it may seem impossible or hard to accomplish. Something good can come out of it once you fight hard and with patience.

Similarly, Chinelo found the film as containing a lesson that the struggle for human rights is indeed a difficult one and in which only the enduring could be victorious. She said she was inspired by the doggedness of some of the film characters "to fight evil at all cost no matter the consequences 
and to bring the offenders to book." Sandra believed the film Bloody Night sounds a note of warning to the Special AntiRobbery Squad (SARS) department of the Nigeria Police Force to be more cautious in their operation to avert human rights violations in the name of fighting crime. Like other discussants, she was convinced that the individual Nigerian has lesson to learn in regard to safeguarding his/her rights. In her words: "The film emphasises that we citizens should be able to recognise our rights and fight for them no matter what the circumstances are." Another discussant Chisom made an equally pertinent observation:

The most important lesson learnt from the film is that anyone can be a victim of injustice but we should not chicken out in fighting for justice even when the hopes of getting it seems gone. One should be brave in fighting for his/her rights.

In the same vein, Obianuju saw something relevant for Nigerians in their dream of achieving a strong human rights culture. Said she:

I can say that the film taught Nigerians a very big lesson in the sense that we Nigerians should learn not to cover up evil; rather we should fight it to make our country a better place.

For Somewhere in Africa, the respondents equally saw some lessons for Nigeria in her attempt towards democratisation, political stability and consequent respect for human rights. According to Nancy:

The film teaches that united we stand, divided we fall. This is seen in the character of Mrs. Archibong and her students. The students stood by her during the periods of trial. They bonded together in order to achieve the right and freedom they deserve. This togetherness should be adopted 
in our society today in order to achieve that which we desire.

Similarly, Frank observed that the storyline of the film embodies a lesson in love, unity and peace for Nigeria. The film, he said, "teaches us that we need love, unity and peace." In the view of Oluchukwu, the film admonishes Nigerians on the beauty of human rights, hence the paramount need to pursue it. Said she:

The film teaches that all humans have freedom of life, freedom of speech, freedom of good living. The film points out that it is good to fight for what you believe in and that it is ideal for the government to always hear the people, respect their views. The film also teaches unity.

Another discussant Jude saw in the film a lesson about the critical role of the press in protecting people's human rights. His words:

The film also teaches the importance of the press as an agent of public opinion which should educate the masses without fear or prejudice. Such proper education and orientation of the citizens on their fundamental human rights will make them know their rights and how to present issues to the government. The film also highlights the fact that through peaceful demonstration, peace and success can be achieved.

In the opinion of Gift, the film Somewhere in Africa represents a wake-up call to Nigeria and Nigerians to the effect that the nation has come of age and must break with her ugly human rights past. The nation must begin to act like one among the nations of our civilised world. Her words:

The film teaches Nigerians that things have changed and it is not the way it was before; that 
the nation should now live more like a civilised people than before. In other words, Nigerians have to improve on their human rights culture and sustain it because it is critical to the growth of the country.

\section{Conclusion}

The above analysis indicate that the two films Bloody Night and Somewhere in Africa mirror the systemic inadequacies in human rights realisation in Nigeria. This is observable from the fact that the two films treat human rights violations within contexts which the country Nigeria is familiar with. Bloody Night is situated within the context of a corrupt system, a corrupt police institution, which continues to be a veritable $\operatorname{cog}$ in the wheel of human rights realisation. This situation has been observed in Nigeria over the years (Human Rights Watch, 2010; Edukugho, 2013). Similarly, Somewhere in Africa presents human rights abuses within the context of dictatorship and political instability. This is an experience which Nigeria's history clearly reveals. Discourses of human rights in Nigeria cannot be complete without reference to her long history of military dictatorship and political instability that often results from coups (Chukwumeirje, 2014).

The two films, in depicting the human rights challenges of Nigeria, offered an ideological sentiment that seeks for a reformed system. The climax of the two films shows this pro-human rights ideology which the producers apparently intended to propagate. The films depict the triumph of human rights, peace, unity and stability. Finally, the FGD data indicate that the audience understood the film's message in the context of the quest for human rights realisation in Nigeria. They were able to relate the situations portrayed in the films to their own real life situations as Nigerians. They were able to reconcile the message with what is happening 
around them such as corrupt police force who abuse human rights, dictatorship, oppression of the poor and so on.

The findings of this research could be summarised by stating that films in Nigeria could serve the purpose of human rights advancement as exemplified by the two films in focus here. For one, the films were able to project the systemic inadequacies of human rights culture in Nigeria and offered an ideological alternative. For another, the audience members were able to relate with the films, grasping their messages in the required contexts. This study is in line with the media system dependency theory which holds that the more we depend on the media for information, education and entertainment, the more likely that the media would exert its influence on us (Baran, 2010, p.256). Based on the foregoing, it could be concluded that film presents for Nigeria a veritable tool for catalysing her democratisation process particularly as it relates to human rights culture. Since films now serve as a major source of entertainment for Nigerians (Ozoemena, 2006), they can go a long way in helping social transformation especially as it relates to human rights.

\section{Emmanuel Onyeka Ebekue \& Somtoo Arinze-Umobi Department of Theatre and Film Studies Nnamdi Azikiwe University, Awka, Nigeria}

\section{References}

Baran, S. J. (2010). Introduction to Mass Communication, Media Literacy and Culture (Sixth Edition). New York: McGraw-Hills.

Centre for Community Journalism and Development (2014). Media and Human Rights. http://www.ccjd.org/programsandprojects/media-andhuman-rights 
Chauncey, S. (2012). Nollywood bound. http://www.resonanceco.com/blog/nollywood-bound/

Chukwumerije, U. (2014). An Appraisal of the Concept and Practice of Human Rights in Post-Independent Nigeria. http://www.senatorchukwumerije.net/id96.html

Edukugho, E. (2013, June 15). Woes and Pains of Domestic Violence. Saturday Vanguard, p.10.

Falayi, K. (2014). Police Admit Killing Missing-in-Custody Man. The Punch.

http://www.punchng.com/feature/saturday-crime/policeadmit-killing-missing-in-custody-man/

Filani, O. (2014). Half of a Yellow Sun movie ban:

Chimamanda Adichie blasts Censors Board. http://dailypost.ng/2014/05/03/half-yellow-sun-movieban-chimamanda-adichie-blasts-censors-board/

Haynes, J. \& Okome, O. (1998). Evolving Popular Media: Nigerian Video Films. Research in African, literatures 29(3).

http://www.jstor.org/discover/10.2307/3820623?uid=373 8032\&uid $=2129 \&$ uid $=2 \&$ uid $=70 \&$ uid $=4 \&$ sid $=21104365$ 676037

Human Rights Watch (2010). Nigeria: Corruption Fueling Police Abuses.

http://www.hrw.org/news/2010/08/17/nigeria-corruptionfueling-police-abuses

Human Rights Watch (2014). World Report 2013. http://www.hrw.org/world-report/2013/countrychapters/nigeria

Ozoemena, G. (2006). "Forging a Link Between Nollywood and Hollywood". http://nigeriamovies.net/news/new3.htm 